International Journal of Instruction e-ISSN: 1308-1470 • www.e-iji.net

Article submission code: 20200709091848

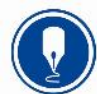

October $2021 \bullet$ Vol.14, No.4

p-ISSN: 1694-609X

pp. 775-790

Received: 09/07/2020

Revision: 22/04/202
Accepted: 17/05/2021

OnlineFirst: 02/09/2021

\title{
Factors Influencing School Teachers' Sense of Belonging: An Empirical Evidence
}

Sandeep Lloyd Kachchhap

PhD, Walailak University, Thailand, slkachchhap@gmail.com

\section{Wilson Horo}

MA, Lotus Adventist English School, India, wilsonhoro4@gmail.com

An educational organization includes a variety of people from different backgrounds, which may include culture, language, tradition, custom, belief and so on. They all work at different levels to meet the distinct goals and objectives of an organization. By extension, schools fit the same profile, in that they are educational organizations. To meet a desired outcome, it is essential for the teachers in a school to work together. This coordination as well as efficiency in the work can exist when there is a sense of belongingness among teachers. This study sought to examine the influence the selected factors had on the sense of belongingness. Using a quantitative approach a sample $(n=186)$ of teachers were selected to test this influence. A cross sectional survey methodology was employed for data collection. Reliable instruments were carefully selected and, before being used, were pilot tested to ensure its reliability in the context. The data was analyzed using descriptive analysis, Pearson correlation and multiple regression. The result of the study revealed that perceived organizational support and organizational climate had a positive influence on teachers' sense of belonging. Additionally, it was identified that organizational climate was a better predictor of teachers' sense of belonging.

Keywords: teachers' sense of belonging, perceived organizational support, organizational climate, teachers, educational organization

\section{INTRODUCTION}

People live in environments in a way that the interaction between man and environment actually determines the future of both (Dearing et al., 2006). Because of this relationship it is possible that factors that are both internal and external to man can influence wellbeing. In fact, it suggested that man is a result of biological and sociocultural influences (Tomljenovic, 2014). Work has taken a central place in many people's lives such that much of a person's waking hours is spent at work (Michaelson et al., 2014). It may, therefore, be argued that an employee is influenced by his work environment. By extension teachers, as much as they are responsible for creating the right atmosphere for

Citation: Kachchhap, S. L., \& Horo, W. (2021). Factors influencing school teachers' sense of belonging: An empirical evidence. International Journal of Instruction, 14(4), 775-790. https://doi.org/10.29333/iji.2021.14444a 
students, are influenced by the environment they are in as well. The term educational environment is multifaceted, typically including physical, emotional and intellectual context wherein the learning takes place. The educational environment is typically shaped by the perspectives a learner has of these contexts and the quality, thereby, is defined by these perspectives (Ergur, 2009). The environment that shapes learning can potentially impact how students are engaged in the classroom, their motivation and how important they feel the learning is to themselves (Hutchinson, 2003).

Educational environments can include atmosphere, number of (formal) learning opportunities and available facilities (Karagiannopoulou \& Christodoulides, 2005). Research has evidenced that the educational environment adds value to the quality of education such that the involvement, success and satisfaction of students is determined by their perception of the environment in which they learn (Schönrock-Adema et al., 2012). The psychosocial environment in educational settings makes it a vital concept in understanding how individuals function on the basis of relationships within the organization (Allodi, 2010). In fact, school climate - often defined by the quality of social relationships - was identified as a factor related to well-being (Ruus et al, 2007).

\section{Need to Belong}

Globalization, among many other phenomena, has led to diversity in current work environments (Martin, 2014). Diversity in the workplace could include differences between people working in the same organization in terms of religion, age, gender, qualifications, tenure, work experience, skills and many more (Patrick \& Kumar, 2012). However, there seems to be some level of ambiguity in how diversity is defined. In order for diversity to work to the advantage of the organization it would be helpful to clearly distinguish functional from social diversity (Simon \& Rowland, 2011). Despite this conceptual ambiguity, owing to globalization, there seems to have been a sudden surge of several forms diversity in many organizations. This is particularly in part because diversity in the workplace was found to have improved innovative performance (Mohammadi, Brostron \& Franzoni, 2017). Moreover, it was specifically established that diversity in knowledge is what enables innovation (Lungeanu \& Contractor, 2015). Despite the many disadvantages or advantages of diversity in the workplace, one thing that is certain is that we cannot escape it. In educational institutions it is characteristic today to find a diverse population both in terms of employees and students. Given the wide migration of students for education and teachers for job prospects, ethnic diversity continues to grow. With this growth in diversity there is a possibility of concern for the need to find affiliation in the workplace in order for pro-organizational attitudes to be manifested.

The need to belong is a fundamental human experience (Hirsch \& Clark, 2018). Belongingness, which is the need to belong, includes the desire to be accepted in and be affiliated to a certain group (Baumeister \& Leary, 1995). The need to affiliate with a group can be unique to a peer group school among school students, co-workers, an athletic team, teaching team, a church group. The need for affiliation goes beyond simply knowing, or being known by other people. On the contrary, receiving attention, being accepted and being supported by group members, along with providing the same 
in reciprocation, is central to belongingness (DeWall, Baumeister \& Vohs, 2008)). Further, it is an experience that allows employees to feel that their performance directly affects the functioning of the organization they belong to. It has been found that employees' need to belong is an antecedent to organizational effectiveness (Bedarkar \& Padita, 2013). Consequently, it is possible that when the workplace environment becomes a place where belongingness is nurtured, employees can potentially perform better. It was also identified that creating a learning experience for beginning teachers aided in the development of a sense of belonging in them (Ussher, 2010). Additionally, employees tend to be successful in achieving goals when the environment is supportive which in turn leads to engagement at work (Bakker, Schaufeli, Leiter \& Taris, 2008). It is quite likely possible that when teachers are provided with guidance when needed, they would feel more committed to being absorbed in work, and by extension, would feel like they belong and satisfied. In fact, satisfied teachers are invaluable assets in any effective educational system (Rezaee, Khoshsima, Zare-Bahtash \& Sarani, 2018)

It is very possible that when the need to belong is left unaddressed, or rather thwarted, it could lead to negative outcomes. This idea was actually confirmed through a series of experiments (Twenge et al., 2003). Among several of the findings in these experiments, it was concluded that participants who experienced rejection perceived life as meaningless and displayed tendencies to escape self-awareness. Additionally, these participants also displayed lethargy and an altered sense of time. These are certainly outcomes that no management would want to see in their employees. On the contrary, prosocial employees would add more value to any organization by actively making contributions when and where needed. For instance, in a school, a prosocial teacher is more likely to offer to help out in the orientation of a newly recruited teacher. In fact, employees may more willingly engage in prosocial behaviours as accepted by the culture of the group they desire to belong to (Twenge et al., 2007). As a result, when employees' need to belong is satisfied through social support and a sense of community, the environment can potentially drive engagement. At the workplace, group membership provides an avenue to nurture social identity through shared activities and mutual care (Hirsch \& Clark, 2018). Consequently, a psychological safe environment is created that caters to employees' need to belong. In such an environment there is a better chance of improved performance and, perhaps, even innovation. Particularly in schools, where teachers often work as a community, it would be very helpful to maintain an environment that nurtures a sense of belonging.

\section{Organizational Climate}

Organizational climate is typically seen as the perception employees develop as a result of the interplay between the employees and the policies, procedures and practices of the workplace (Schneider, Ehrhart \& Macey, 2013). The environment within an organization characterized by leadership, roles, communication, interactions among individuals, shared values and reward systems among others, can impact employees' desire for success in the workplace (Neal, Griffin, Hart, 2000). In fact, leadership seems to have a strong role in shaping organizational climate (Grojean, Resick, Dickson, \& Smith, 2004). By extens ion, looking at managers as leaders, employees' perception 
of organizational climate has been attributed to human resource management style and practices (Zhang \& Liu, 2010). This would mean that the perceptions that employees had of their managers and their style of management shapes the organizational climate. A study assessing the impact of organizational climate on individual behaviour of employees found that safety climate mediated the influence of organizational climate on individual behaviour (Neal, Griffin, Hart, 2000). In other words, it may imply that individual behaviour within an organization is determined by the safety climate, which is influenced by the context provided by the organizational climate. Sometimes the environment can cause job stress that often impacts the quality of work which includes the possibility of wrecked work relationships (Abdullah \& Ismail, 2019).

Individually what employees perceive organizational management to be is the psychological climate at an individual level. However, when the perception is shared with other colleagues it becomes a concept at the organizational level which can affect work engagement significantly (Chaudhary, Rangnekar \& Barua, 2014). The same can be extended to schools and how teachers' engagement in work is affected by the management practices in the school. Further, school climate was described as the perceptions that teachers had of the working environment that is shaped by the formal and informal organization, the quality of relations with colleagues and leadership (Hoy, 1990). Additionally, Rapti (2013) comprehensively defined school climate as a mixture of factors related to all the stakeholders--teachers, parents, students and leaders. She pointed out that the values, beliefs, and behaviour of students and parents, the job satisfaction of employees and the leadership style shape the climate of a school. A positive school climate is said to have positive student outcomes (Loukas, 2007). Put simply, we can say that the school climate has the potential to influence how teachers and students in a school feel. Further, it could imply that the climate of the school can influence the satisfaction of both students and teachers and, consequently the quality of academic affairs in the school. Organizational climate as applied to schools, would mean the perceptions that both employees and students have of the environment within the school that differentiates it from others.

\section{Perceived Organizational Support}

It is quite naturally desirous for employers to have employees who are productive, dedicated and loyal. Typically, employees who are loyal and dedicated tend to be more productive and engage in tasks that are favourable for the organization, going beyond the required duties (Osborne \& Hammoud, 2017). Additionally, such employees have a positive influence on their peers, potentially improving overall participation. However, in order for employees to be loyal and dedicated they must first be engaged in their work (Macey \& Schneider, 2008). It was also found that when employees feel valued and find meaning in their work, they are more likely to be engaged in it (Markos \& Sridevi, 2010). This means that a feeling of value can enhance engagement at work, eventually leading to heightened commitment. Further, a retention study found that employees who felt valued at work also felt more connected to and identified with their organization (Latif, 2012). 
Perceived organizational support has been referred to as the perceptions that employees have regarding the degree to which their contributions are valued and if the organization cares for their well-being (Rhoades \& Eisenberger, 2002). In a similar vein, Conway (2015) explained that employees make efforts to benefit the organization depending on how the organization treats and values them. This simply implies that employees are concerned about how the organization values them because this helps to add meaning to their work life. Further, it was empirically confirmed that when employees perceived their organizations to be supportive they readily created psychological attachments with the organizations (Arshadi \& Hayavi, 2013). This means that when employers were perceived to be caring enough to maintain a work environment favourable to the socioemotional needs of employees, an attachment with the workplace was consequential. By extension, we may say that a sense of belonging among employees can be created by improving the perceptions employees have about their employing organizations. Some ways an organization can show support to its employees are a) creating an environment that supports and encourages trust, creativity, fairness and positive communication, b) encouraging good practices through rewards and recognition, and c) being transparent and consistent with policies and performance evaluation criteria (Nayir, 2012). Sense of belonging, conceptually a subset of commitment, has been found to be related to perceived organizational support (Rhoades \& Eisenberger, 2002; Nayir, 2012).

As presented in the discussion above, satisfying the need to belong can help improve the performance of employees. Additionally, it is possible that when employees hold a unified perspective of the employing organization to be caring and supportive of their needs there is a better likelihood of developing an attachment with their organizations. Likewise, when the organizational climate is suitable for psychological bonding similar outcomes can be expected. Considering the costs included in attrition rates, it is timely that organizations consider employees' sense of belonging to potentially reduce turnover. Especially, given that turnover is particularly an issue highlighted in the teaching profession (Carver-Thomas, Darling-Hammond, 2013)

Consequently, the main objective of this study is to test perceived organizational support and organizational climate as factors that affect teachers' sense of belonging. The following three research questions were formulated to help achieve the objective of this study.

1. How is organizational climate related to sense of belonging?

2. How is perceived organizational support related to sense of belonging?

3. What is the influence of organizational climate and perceived organizational support on sense of belonging?

\section{METHOD}

Since the study endeavoured to test the influence of the selected variables on the sense of belonging, it employed quantitative methods to achieve that end. Quantitative research is based on the measurement of quantity and is best suited for testing purposes (Creswell, 2003). It is applicable to phenomena that can be expressed in terms of 
quantity (Kothari 2004). Quantitative methods emphasize objective measurements and the numerical analysis of data that is typically generated through questionnaires, and surveys. This design was deemed fit since it used numerical data to test effects in order to explain teachers' sense of belonging. Additionally, this study was approved by the Institutional Review Board (IRB) of Walailak University (Approval No. WUEC-21093-01)

\section{Participants}

Probability sampling is typically the type of sampling design selected for quantitative studies (Best \& Kahn, 2006). This is because it allows every member of the population to have an equal chance of being part of the sample. Consequently, owing to varying time schedules of the teachers, convenient sampling was employed to recruit a total of 192 teachers from the three selected schools in Pune, India. These schools were selected based on permissions granted to collect data from them. As a result, 186 surveys were returned at a rate of $93.5 \%$ and this made up the data for the study.

The demographic distribution of the teachers in terms of gender included $64(34.4 \%)$ males and $122(65.6 \%)$ females. In terms of tenure 69 teachers (37.1\%) had 0-5 years; 62 teachers $(33.3 \%)$ had $6-10$ years; 37 teachers $(19.9 \%)$ had $11-15$ years; 12 teachers had (6.5\%) 16-20 years; and 6 teachers $(3.2 \%)$ had above 20 years of service. Clearly, the highest number of respondents, in terms of gender, were females and in terms of tenure, were those who were relatively new to their schools ( $0-5$ years).

\section{Instruments}

The survey instrument used in this research included three standardized scales. The questionnaire for this study had two sections--demographic variables and items measuring the three variables in the study. Items measuring sense of belonging were adapted from Sense of Belonging Scales (SOBS) (Hagerty \& Patusky, 1995). "I wonder if I really fit here" and "it is important to me that the work I do is valued" are sample questions measuring a sense of belonging. Items measuring organizational climate were adapted from Organizational Climate Scales (OCS) (Patterson, West, Shakleton, Dawson, Maitlis, Robinson \& Wallace, 2005), and sample questions from this scale include "People at the top tightly control the work of those below them" and "it is important to check things first with the supervisor before taking a decision". Perceived organizational support, adopted from Scales of Perceived Organizational Support (SPOS) (Eisenberger \& Huntington 1984). Sample questions from this instrument include "the school values my contribution to its well-being" and "the school really cares about my well-being". The key factors that help assess the quality of any measuring instrument is its reliability and validity (Best \& Kahn, 2006). Consequently, a pilot test was conducted to ensure reliability of the instrument that yielded $\alpha=0.79$, which was deemed reliable. 


\section{FINDINGS \& DISCUSSION}

A descriptive analysis of the three variables in the study-perceived organizational support, organizational climate and sense of belonging-indicate that their sense of belonging is moderately positive $(\mathrm{M}=3.72, \mathrm{SD}=0.57)$. Further, the respondents' perception of the organization to be supportive was found to be moderately positive $(\mathrm{M}=3.46, \mathrm{SD}=0.64)$, just as that of organizational climate $(\mathrm{M}=3.28, \mathrm{SD}=0.46)$. These inferences were made based on the results presented in Table 1. A closer look at the results suggests that organizational climate had the lowest mean values. Reflecting on the items "People at the top tightly control the work of those below them" and "it is important to check things first with the supervisor before taking a decision" it may imply that the climate of the organization may be more controlling that the employees would prefer. Further, the implications of the findings in regards to perceived organizational support was also suggestive that the teachers in the selected school have a moderately positive perception. A look at the items "the school values my contribution to its well-being" and "the school really cares about my well-being" would help in determining this interpretation. Finally, in regards to sense of belonging, it appears that teachers' sense of belonging, although not very strong, was positive.

\section{Relationship between Organizational Climate and Sense of Belonging}

In order to answer the first research question - relationship between organizational climate and sense of belonging - Pearsons Correlation analysis of the data was done and the results are presented in Table 2 . The results indicate that the relationship between organizational climate and sense of belonging was found to be moderately strong and positive $(\mathrm{r}=0.433, p=<0.005)$. This would imply that the climate in the organization is related to whether employees feel a sense of ownership at the workplace or not. Further, the climate within an organization is related to the degree to which employees care about their presence at their workplace. This was consistent with prior research that found a relationship between organizational climate and a sense of belonging as a sub dimension of commitment (Berberoglu, 2018; Boateng et al., 2014). This finding suggests that the way communication within an organization is passed, management control is set, and other practices that create the organizational climate is related to how an employee feels like they fit in. Further, it is also related to whether employees feel like their work is valued by their organization.

\section{Relationship between Perceived Organizational Support and Sense of Belonging}

The results suggest that there is a moderately strong and positive relationship between teachers' perceived organizational support and their sense of belonging $(\mathrm{r}=0.41$, $p<0.005$ ). This simply implies that the perception teachers have of their organization being supportive is related to how they fit into their organizations. This is in line with earlier research that found a strong relationship between perceived organizational support and employee's sense of belonging (Choi, 2019; Davilia \& Garcia, 2012). It was found that a supportive work environment acted as a buffer on work attitudes such as a sense of belonging. Additionally, it was found that perceived organizational support was closely related to the sense of belonging as a dimension of commitment among industrial 
employees in Iran (Arshadi, 2011). This relationship was explained in a way that perceived organizational support was related to a sense of felt obligation, which eventually curbed turnover intention. Put simply, there seems to be a strong likelihood that when employees feel that the organization is supportive towards its employees then they make care about the contributions they make to the organization.

Table 1

Descriptive test results of the variables in the study

\begin{tabular}{llllll}
\hline & $\mathrm{N}$ & Minimum & Maximum & Mean & Std. Deviation \\
\hline MSOB & 186 & 2.64 & 6.55 & 3.7268 & .57969 \\
\hline MPOS & 186 & 1.38 & 4.88 & 3.4666 & .64463 \\
\hline MOC & 186 & 2.12 & 4.47 & 3.2875 & .46073 \\
\hline Valid N (listwise) & 186 & & & &
\end{tabular}

Table 2

Correlation test results

\begin{tabular}{lllll}
\hline \multirow{2}{*}{ MSOB } & & MSOB & MPOS & MOC \\
\cline { 2 - 5 } & Pearson Correlation & 1 & & \\
\cline { 2 - 5 } & Sig. (2-tailed) & 186 & & \\
\hline \multirow{2}{*}{ MPOS } & Pearson Correlation & $.408^{* *}$ & 1 & \\
\cline { 2 - 5 } & Sig. (2-tailed) & .000 & & 1 \\
\cline { 2 - 5 } & $\mathrm{N}$ & 186 & 186 & \\
\hline MOC & Pearson Correlation & $.433^{* *}$ & $.656^{* *}$ & 1 \\
\cline { 2 - 5 } & Sig. (2-tailed) & .000 & .000 & \\
\cline { 2 - 5 } & $\mathrm{N}$ & 186 & 186 & 186 \\
\hline
\end{tabular}

**. Correlation is significant at the 0.01 level (2-tailed)

MOC (Organizational Climate),

MPOS (Perceived Organizational Support)

MSOB (Sense of Belonging)

The influence of organizational climate and perceived organizational support on sense of belonging

Answering the last research question of the study - the influence of organizational climate and perceived organizational support on sense of belonging - a regression analysis was carried out. The results of this test are presented in Table 3. The model suggests that perceived organizational support and organizational climate are significant predictors of sense of belonging $(p=0.000)$. Further, the model indicates that both the independent variables - perceived organizational support and organizational climateexplain $20 \%$ variance in sense of belonging $(\mathrm{r} 2=0.21, \mathrm{~F}(2,184=25.148, \mathrm{p}=0.000)$. Additionally, the model also indicates that the organizational climate $(\boldsymbol{\beta}=0.29, t(186)=$ $3.36, p<0.005)$ was a better predictor than perceived organizational support in explaining sense of belonging. 
Table 3

Regression analysis test results Model Summary

\begin{tabular}{|c|c|c|c|c|c|c|c|c|}
\hline \multirow{2}{*}{\multicolumn{2}{|c|}{ Model R }} & \multirow[b]{2}{*}{$\begin{array}{l}\mathrm{R} \\
\text { Square }\end{array}$} & \multirow[b]{2}{*}{$\begin{array}{l}\text { Adjusted R } \\
\text { Square }\end{array}$} & \multirow[b]{2}{*}{$\begin{array}{l}\text { Std. Error of the } \\
\text { Estimate }\end{array}$} & \multicolumn{4}{|c|}{ Change Statistics } \\
\hline & & & & & $\begin{array}{l}\text { R Square } \\
\text { Change }\end{array}$ & $\begin{array}{l}\mathrm{F} \\
\text { Change }\end{array}$ & df1 df2 & $\begin{array}{l}\text { Sig. F } \\
\text { Change }\end{array}$ \\
\hline 1 & $.463^{\mathrm{a}}$ & .215 & .206 & .51650 & .215 & 25.148 & 184 & .000 \\
\hline
\end{tabular}

\begin{tabular}{|c|c|c|c|c|c|}
\hline \multicolumn{6}{|l|}{ ANOVA } \\
\hline Model & Sum of Squares & df & Mean Square & $\mathrm{F}$ & Sig. \\
\hline 1 Regression & 13.418 & 2 & 6.709 & 25.148 & $.000^{\mathrm{a}}$ \\
\hline Residual & 49.087 & 184 & .267 & & \\
\hline Total & 62.504 & 186 & & & \\
\hline
\end{tabular}

a. Predictors: (Constant), MOC (Organizational Climate), MPOS (Perceived Organizational Support)

b. Dependent Variable: MSOB (Sense of Belonging)

\begin{tabular}{llllll}
\hline Coefficients & \multicolumn{1}{l}{} & & \\
\hline Model & Unstandardized Coefficients & Standardized Coefficients & & \\
\hline 1 (Constant) & 1.847 & Std. Error & Beta & t & Sig. \\
\hline MPOS & .196 & .275 & & 6.714 & .000 \\
\hline MOC & .365 & .078 & .218 & 2.513 & .013 \\
\hline
\end{tabular}

a. Dependent Variable: MSOB (Sense of Belonging)

The findings of this study resulted in the following regression equation

$$
\mathrm{y}=1.847(\mathrm{a})+0.218\left(\boldsymbol{\beta}_{\mathrm{POS}}\right)+0.290\left(\boldsymbol{\beta}_{\mathrm{OC}}\right)
$$

Where $\mathrm{Y}=$ Sense of Belonging (dependent variable);

$\mathrm{a}=$ constant value or $Y$ intercept;

$\boldsymbol{\beta}_{\mathrm{POS}}=$ perceived organizational support (independent variable);

$\boldsymbol{\beta}_{\mathrm{OC}}=$ organizational climate (independent variable).

The results suggest that the predictive model accounts for $20 \%$ variance in sense of belonging among teachers. This implies that $80 \%$ of variance is unaccounted for in this model and there are other factors, not hypothesized in this model, that explain sense of belonging. Through this model we can see that organization climate was a better predictor of sense of belonging than perceived organizational support. Organizational climate was previously found to be an important factor in determining positive job attitudes of employees (Berberoglu, 2018; Casto \& Martin, 2010). In this study of teachers it was evident that the climate within is a significant factor in aiding their sense 
of belonging to the school. The way control is set and the degree of autonomy teachers have in fulfilling their duties are some elements that help in improving the attachment teachers have with their institutions. This sense of attachment is useful for improved organizational performance since the bond shared between employee and organization can yield positive attitudes (Judge \& Kemmeyer-Mueller, 2012). Further, when these attitudes are shared collectively it may potentially propel the organization forward. School teachers are often expected to work in teams, particularly because it was found to be effective in improving the teaching and learning process (Conley, Fauske \& Pounder, 2004). When collaboration among teachers takes place in matters concerning instruction, curriculum and professional development, there is a better chance in improved student achievement (Goddard, Goddard \& Tschannen-Moran, 2007).

Since teaching is a cooperative effort where teachers work together to teach different subjects, their ability to work together would go a long way in serving students. It has already been established that teacher collegiality improves positive factors such as organizational and professional commitment, and consequently, student performance (Shah, 2012). This outcome is particularly real for beginning teachers who normally need a more strategically planned, systemic assistance which can reduce teacher attrition (Hudson, 2012). The benefits of a sense of belonging among teachers for students are addressed in the discussion of professional learning communities. A supportive leadership has shown to go a long way in empowering teachers to buy-in to the shared vision, engage in constant improvement and extend peer support (Owen, 2014).

Social exchange theories have pointed out to employment being an exchange of employee effort for tangible benefits (Redmond, 2015). The exchange can also be made for socio-emotional benefits which may be a need an employee experiences at some degree. Taking this into account, employers may provide what employees need in order to elicit the desired outcomes in employees, thereby, strengthening the employeeorganization relationship. Consequently, reciprocity is manifested in organizations leading to positive and desirable outcomes. Typically, in this exchange both parties tend to benefit and in school contexts, the students also benefit as a result. It may therefore be useful for academic heads to foster an atmosphere that is less divisive and provide support for teacher efforts and needs. In doing so, they may potentially improve the quality of teaching and, as a result, the performance of students.

\section{CONCLUSION}

This research provides empirical evidence for the positive influence of perceived organizational support and organizational climate on teachers' sense of belonging. Further, it evidenced that organizational climate is a better predictor of a sense of belonging than perceived organizational support. The relevance of sense of belonging among teachers cannot be undermined due to the benefits it has to the whole teaching and learning effort. Schools, being societies themselves, have the responsibility of training students for the society at large. If teachers themselves fail to experience a collegial atmosphere within which a unified target is to be met, this basic goal of education would be left unattained. Creating a climate that fosters a sense of belonging among teachers may be one major step in helping achieve this goal, which is established 
through this study. Additionally, this study has also verified that efforts to help teachers build a perception of a supportive management can also enhance teachers' attachment with their organization. The findings from this study may be extended to other settings, but with careful consideration of contexts. This study included two variables as determinants of sense of belonging leaving room for future research to investigate other variables that may possibly account for the remaining $80 \%$ variance in sense of belonging of teachers.

\section{ACKNOWLEDGMENTS}

The authors would like to thank the participants for their willingness to participate in the study. Additionally, this study was supported by the School of Languages and General Education, Walailak University.

\section{REFERENCES}

Abdullah, A. S., \& Ismail, S. N. (2019). A Structural Equation Model Describes Factors Contributing Teachers' Job Stress in Primary Schools. International Journal of Instruction, 12(1), 1251-1262. https://doi.org/10.29333/iji.2019.12180a

Allodi, M. W. (2010). The meaning of social climate of learning environments: Some reasons why we do not care enough about it. Learning Environments Research, 13(2), 89-104. https://link.springer.com/article/10.1007/s10984-010-9072-9

Arshadi, N. (2011). The relationships of perceived organizational support (POS) with organizational commitment, in-role performance, and turnover intention: Mediating role of felt obligation. Procedia-Social and Behavioral Sciences, 30, 1103-1108. https://doi.org/10.1016/j.sbspro.2011.10.215

Arshadi, N., \& Hayavi, G. (2013). The effect of perceived organizational support on affective commitment and job performance: mediating role of OBSE. Procedia-Social and Behavioral Sciences, 84, 739-743. https://doi.org/10.1016/j.sbspro.2013.06.637

Bakker, A. B., Schaufeli, W. B., Leiter, M. P., \& Taris, T. W. (2008). Work engagement: An emerging concept in occupational health psychology. Work and Stress, 22(3), 187-200. https://doi.org/10.1080/02678370802393649

Baumeister, R. F., \& Leary, M. R. (1995). The need to belong: desire for interpersonal attachments as a fundamental human motivation. Psychological Bulletin, 117(3), 497. http://persweb.wabash.edu/facstaff/hortonr/articles\%20for\%20class/baumeister\%20and \%20leary.pdf

Bedarkar, M., \& Pandita, D. (2014). A study on the drivers of employee engagement impacting employee performance. Procedia-Social and Behavioral Sciences, 133, 106115. https://doi.org/10.1016/j.sbspro.2014.04.174

Berberoglu, A. (2018). Impact of organizational climate on organizational commitment and perceived organizational performance: empirical evidence from public hospitals. BMC health services research, 18(1), 399. https://bmchealthservres.biomedcentral.com larticles/10.1186/s12913-018-3149-z 
Best, J.W. \& Kahn, J. (2006) Research in Education. New Delhi: Prentice Hall of India Pvt. Ltd.

Boateng, I. A., Kanyandewe, S., \& Sassah, M. (2014). Organizational climate a tool for achieving employees job satisfaction in Ghanaian manufacturing firms. International Journal of Academic Research in Business and Social Sciences, 4(9), 166. http://dx.doi.org/10.6007/IJARBSS/v4-i9/1146

Carver-Thomas, D., Darling-Hammond, L. (2017). Teacher turnover: Why it matters and what we can do about it. Learning Policy Institute. Retrieved from https://files.eric.ed.gov/fulltext/ED606807.pdf

Castro, M. L., \& Martins, N. (2010). The relationship between organisational climate and employee satisfaction in a South African information and technology organization. SA Journal of industrial psychology, 36(1), 1-9. https://doi.org/10.4102/sajip.v36i1.800

Chaudhary, R., Rangnekar, S., \& Barua, M. K. (2014). Organizational climate, climate strength and work engagement. Procedia-Social and Behavioral Sciences, 133, 291303. https://core.ac.uk/download/pdf/82727803.pdf

Choi, Y. (2019). A study of the effect of perceived organizational support on the relationship between narcissism and job-related attitudes of Korean employees. Cogent Business and Management, 6(1), 1573486. https://www.tandfonline.com/doi/full/10. $\underline{1080 / 23311975.2019 .1573486}$

Conley, S., Fauske, J., \& Pounder, D. G. (2004). Teacher work group effectiveness. Educational Administration Quarterly, 40(5), 663-703. https://doi.org/10.1177/0013161 $\underline{\mathrm{X} 04268841}$

Conway, E. (2015). Perceived organizational support. Wiley Encyclopedia of Management, 1-2. https://doi.org/10.1002/9781118785317.weom110285

Creswell, J. (2003). Research design: Qualitative, quantitative and mixed methods approaches (2nd ed.). Thousand Oaks, CA: SAGE Publications.

Davila, M. C., \& García, G. J. (2012). Organizational identification and commitment: correlates of sense of belonging and affective commitment. The Spanish journal of psychology, 15(1), 244-255. DOI: https://doi.org/10.5209/rev_SJOP.2012.v15.n1.37316

Dearing, John. A ., Battarbee, R., Dikau, R.,Larocque, I. \& Oldfield, F. (2006). Humanenvironment interactions: Learning from the past. Regional Environmental Change. 6. 1-16. 10.1007/s10113-005-0011-8. https://link.springer.com/article/10.1007/s10113$\underline{005-0011-8}$

DeWall, C. N., Baumeister, R. F., \& Vohs, K. D. (2008). Satiated with belongingness? Effects of acceptance, rejection, and task framing on self-regulatory performance. Journal of Personality and Social Psychology,95(6), 1367. doi: $10.1037 / \mathrm{a} 0012632$ 
Eisenberger, R., Huntington, R., Hutchison, S., \& Sowa, D. (1986). Perceived organizational support. Journal of Applied psychology,71(3), 500. http://www.academia.edu/download/36107567/Perceived_Organizational_Support.pdf

Ergur, D. O. (2009). How can education professionals become emotionally intelligent? Procedia-Social and Behavioral Sciences, 1(1), 1023-1028. https://doi.org/10.1016/j.sbspro.2009.01.183

Goddard, Y. L., Goddard, R. D., \& Tschannen-Moran, M. (2007). A theoretical and empirical investigation of teacher collaboration for school improvement and student achievement in public elementary schools. Teachers College Record, 109(4), 877-896. https://education.illinoisstate.edu/downloads/casei/collaboration_studentachievement.pd $\underline{\mathrm{f}}$

Grojean, M. W., Resick, C. J., Dickson, M. W., \& Smith, D. B. (2004). Leaders, values, and organizational climate: Examining leadership strategies for establishing an organizational climate regarding ethics. Journal of Business Ethics, 55(3), 223-241. https://link.springer.com/article/10.1007/s10551-004-1275-5

Hagerty, B. M. K., \& Patusky, K. (1995). Developing a measure of sense of belonging. Nursing Research, 44(1), 9-13. https://doi.org/10.1097/00006199-199501000-00003

Hirsch, J. L., \& Clark, M. S. (2019). Multiple paths to belonging that we should study together. Perspectives on Psychological Science, 14(2), 238-255. https://clarkrelationshiplab.yale.edu/sites/default/files/files/HirschClark(2019).pdf

Hoy, W. K. (1990). Organizational climate and culture: A conceptual analysis of the school workplace. Journal of educational and psychological consultation, 1(2), 149168. https://doi.org/10.1207/s1532768xjepc0102_4

Hudson, P. (2012). How can schools support beginning teachers? A call for timely induction and mentoring for effective teaching. Australian Journal of Teacher Education, 37(7), 6. https://files.eric.ed.gov/fulltext/EJ995200.pdf

Hutchinson, L. (2003). Educational environment. British Medical Journal, 326(7393), 810-812. 10.1136/bmj.326.7393.810

Judge, T. A., \& Kammeyer-Mueller, J. D. (2012). Job attitudes. Annual Review of Psychology, 63, 341-367. https://doi.org/10.1146/annurev-psych-120710-100511

Karagiannopoulou, E., \& Christodoulides, P. (2005). The impact of Greek university students' perceptions of their learning environment on approaches to studying and academic outcomes. International Journal of Educational Research, 43, 329-350. https://doi.org/10.1016/j.ijer.2006.05.002

Kothari, C. R. (2004). Research methodology: Methods and techniques. New Delhi: New Age International. 
Latif, K. F. (2012). An integrated model of training effectiveness and satisfaction with employee development interventions. Industrial and Commercial Training, 44, 211222. doi:10.1108/0019785121123147

Loukas, A. (2007). What is school climate? High-quality school climate is advantageous for all students and may be particularly beneficial for at-risk students. Leadership Compass, 5 (1), 1-3. https://www.naesp.org/sites/default/files/resources/2/Leadership_ Compass/2007/LC2007v5n1a4.pdf

Lungeanu, A., \& Contractor, N. S. (2015). The effects of diversity and network ties on innovations: The emergence of a new scientific field. American Behavioral Scientist, 59(5), 548-564. https://doi.org/10.1177/0002764214556804

Macey W.H and Schneider B. (2008). The meaning of employee engagement. Industrial and Organizational Psychology, 1 (1), 3-30. DOI: https://doi.org/10.1111/j.1754-9434 .2007.0002.x

Markos, S., \& Sridevi, M. S. (2010). Employee engagement: The key to improving performance. International Journal of Business and Management, 5(12), 89. 10.5539 /ijbm.v5n12p89

Martin, G. C. (2014). The effects of cultural diversity in the workplace. Journal of Diversity Management (JDM), 9(2), 89-92. DOI https://doi.org/10.19030/jdm.v9i2.8974

Michaelson, C., Pratt, M. G., Grant, A. M., \& Dunn, C. P. (2014). Meaningful work: Connecting business ethics and organization studies. Journal of Business Ethics, 121(1), 77-90. DOI 10.1007/s10551-013-1675-5

Mohammadi, A., Broström, A., \& Franzoni, C. (2017). Workforce composition and innovation: how diversity in employees' ethnic and educational backgrounds facilitates firm-level innovativeness. Journal of Product Innovation Management, 34(4), 406-426. https://doi.org/10.1111/jpim.12388

Nayir, F. (2012). The Relationship between perceived organizational support and teachers' organizational commitment. Eurasian Journal of Educational Research, 48, 97-116. https://files.eric.ed.gov/fulltext/EJ1057713.pdf

Neal, A., Griffin, M. A., \& Hart, P. M. (2000). The impact of organizational climate on safety climate and individual behavior. Safety Science, 34(1-3), 99-109. https://doi.org/10.1016/S0925-7535(00)00008-4

Osborne, S., \& Hammoud, M. S. (2017). Effective employee engagement in the workplace. International Journal of Applied Management and Technology, 16(1), 4. https://scholarworks.waldenu.edu/cgi/viewcontent.cgi?article $=1239 \&$ context=ijamt

Owen, S. (2014). Teacher Professional Learning Communities: Going beyond Contrived collegiality toward challenging debate and collegial learning and professional growth. Australian Journal of Adult Learning, 54(2), 54-77. https://files.eric.ed.gov /fulltext/EJ1033925.pdf 
Patrick, H. A., \& Kumar, V. R. (2012). Managing workplace diversity: Issues and challenges. Sage Open, 2(2), 2158244012444615. DOI: 10.1177/2158244012444615

Patterson, M. G., West, M. A., Shackleton, V. J., Dawson, J. F., Lawthom, R., Maitlis, S., \& Wallace, A. M. (2005). Validating the organizational climate measure: links to managerial practices, productivity and innovation. Journal of organizational Behavior, 26(4), 379-408. https://doi.org/10.1002/job.312

Rapti, D. (2013). School climate as an important component in school effectiveness. Academicus International Scientific Journal, 4(08), 110-125. https://ideas.repec.org /a/etc/journl/y2013i8p110-125.html

Redmond, M. V. (2015) Social Exchange Theory. English Technical Reports and White Papers. 5.https://lib.dr.iastate.edu/engl_reports/5/

Rezaee, A., Khoshsima, H., Zare-Bahtash, E., \& Sarani, A. (2018). A Mixed Method Study of the Relationship between EFL Teachers' Job Satisfaction and Job Performance in Iran. International Journal of Instruction, 11(4), 577-592. https://doi.org/10.12973 /iji.2018.11425a

Rhoades, L., \& Eisenberger, R. (2002). Perceived organizational support: A review of the literature. Journal of Applied Psychology, 87, 698-714. https://doi.org/10.1037 /0021-9010.87.4.698

Ruus, V. R., Veisson, M., Leino, M., Ots, L., Pallas, L., Sarv, E. S., \& Veisson, A. (2007). Students'well-being, coping, academic success, and school climate. Social Behavior and Personality: an International Journal,35(7), 919-936. https://doi.org /10.2224/sbp.2007.35.7.919

Schneider, B., Ehrhart, M. G., \& Macey, W. H. (2013). Organizational climate and culture. Annual Review of Psychology, 64, 361-388. https://www.annualreviews.org/doi /abs/10.1146/annurev-psych-113011-143809

Schönrock-Adema, J., Bouwkamp-Timmer, T., van Hell, E. A., \& Cohen-Schotanus, J. (2012). Key elements in assessing the educational environment: where is the theory? Advances in Health Sciences Education, 17(5), 727-742. doi: 10.1007/s10459-0119346-8

Shah, M. (2012). The importance and benefits of teacher collegiality in schools-A literature review. Procedia-Social and Behavioral Sciences, 46, 1242-1246. https://core.ac.uk/download/pdf/81212847.pdf

Simons, S. M., \& Rowland, K. N. (2011). Diversity and its impact on organizational performance: The influence of diversity constructions on expectations and outcomes. Journal of Technology Management and Innovation, 6(3), 171-183. https://scielo .conicyt.cl/pdf/jotmi/v6n3/art13.pdf

Tomljenović, A. (2014). Effects of internal and external environment on health and well-being: from cell to society. Collegium Antropologicum,38(1), 367-372. https://www.collantropol.hr/antropo/article/view/509/488 
Twenge, J. M., Baumeister, R. F., DeWall, C. N., Ciarocco, N. J., \& Bartels, J. M. (2007). Social exclusion decreases prosocial behavior. Journal of Personality and Social Psychology, 92(1), 56. DOI: 10.1037/0022-3514.92.1.56

Twenge, J. M., Catanese, K. R., \& Baumeister, R. F. (2003). Social exclusion and the deconstructed state: time perception, meaninglessness, lethargy, lack of emotion, and self-awareness. Journal of Personality and Social Psychology, 85(3), 409. DOI: 10.1037/0022-3514.85.3.409

Ussher, B. (2010). Involving a village: Student teachers' sense of belonging in their school-based placement. Asia-Pacific Journal of Teacher Education, 38(2), 103-116. https://doi.org/10.1080/13598661003677614

Zhang, J., \& Liu, Y. (2010). Organizational climate and its effects on organizational variables: An empirical study. International Journal of Psychological Studies, 2(2), 189. DOI:10.5539/ijps.v2n2p189 